\title{
Hepatic Expression of Insulin-Like Growth Factor-1 in Underfed Pregnant Ewes
}

\author{
Victoria de Brun ${ }^{1}$, Ana Meikle ${ }^{1}$, Alberto $\mathrm{Casal}^{2}$, Mariana Carriquiry ${ }^{2}$, Claudia Menezes ${ }^{1}$, Fernando Forcada ${ }^{3}$, \\ Cecilia Sosa ${ }^{3}$ and José Alfonso Abecia ${ }^{3}$ \\ 1. Laboratory of Animal Endocrinology and Metabolism, Veterinary Faculty, University of La República, Lasplaces 1550, \\ Montevideo 11600, Uruguay \\ 2. Department of Animal Production and Grazing, Agronomy Faculty, University of La República, Garzón 780, Montevideo 12900, \\ Uruguay \\ 3. Aragon Environmental Research Institute, Department of Animal Production and Food Science, University of Zaragoza, Miguel \\ Servet 177, Zaragoza 50013, Spain
}

\begin{abstract}
The liver is one of the most important visceral organs, which represents a large contribution to whole animal energy expenditure and the major synthetic site of insulin-like growth factor-1 (IGF-1) peptide. Decreased plane of nutrition acts by reducing the metabolic rate and mass of metabolic tissues, such as liver. Also, undernutrition results in the reduced circulating IGF-1 concentrations, due to the uncoupled growth hormone-IGF (GH-IGF) axis. This study investigated whether a 22-day period of undernutrition (half maintenance) could affect liver mass and IGF-1 protein and gene expression. Sixteen pregnant ewes fed all $(n=$ 9) or half $(n=7)$ of their maintenance energy requirements were slaughtered on day 7 of pregnancy (oestrus $=$ day 0 ). Body and liver mass, IGF-1 plasmatic concentrations and liver IGF-1 mRNA and protein expression were determined. Liver mass and the proportion of liver mass to empty body weight were lower in underfed animals. While IGF-1 plasmatic concentrations were lower in undernourished ewes, no differences in liver mRNA expression were found. This is the first time that differences in immunohistochemistry intensity and total content are reported in sheep. In summary, the decreased plasma IGF-1 concentrations induced by undernutrition in ewes was not associated with its reduced hepatic mRNA or protein expression, but to a decrease in liver mass.
\end{abstract}

Key words: Undernutrition, insulin-like growth factor-1, liver mass, sheep.

\section{Introduction}

In ruminants, visceral organs represent about $6 \%-10 \%$ of body weight, but they account for $40 \%-50 \%$ of whole body protein synthesis and heat production [1, 2]. The liver is one of the most important visceral organs, as it plays a key role in metabolism affecting efficiency of energy and nutrient utilization. Although the liver represents a small (1\%-2\%) proportion of animal body weight, it has a large (17\%-31\%) contribution to whole animal energy expenditure [1, 3]. Adaptability of ruminants to

Corresponding author: Victoria de Brun, M.Sc., research fields: metabolism, reproductive physiology and molecular biology. nutrient restriction depends on the capacity of their endocrine and metabolic mechanisms to maintain homeostasis [4]. It has been previously reported in several species that the decreased plane of nutrition acts at the metabolic level by reducing the metabolic rate and mass of metabolic tissues, such as liver [5, 6]. However, there were not found plenty information about dietary factors regulating visceral mass at the cellular and molecular levels in sheep. The liver is thought to be the major synthetic site of the insulin-like growth factor-1 (IGF-1) peptide [7], but also studies on knockout mice demonstrate the importance of the extrahepatic source of IGF-1, since there are evidence that liver-derived IGF-1 is not 
required for postnatal growth [8, 9]. Some immunohistochemical studies have demonstrated the existence of this peptide in the liver of mammals, such as cattle, swine and rat [10], and chicken [11], but no studies on IGF-1 protein localization in the ruminant hepatocyte were found.

During undernutrition, the growth hormone (GH)-IGF axis uncouples in the liver, which results in reduction in circulating IGF-1 concentrations, despite high $\mathrm{GH}$ concentrations [12]. In previous studies, it has been observed that ewes offered half of the maintenance diet $(0.5 \mathrm{M})$ presented the decreased plasma IGF-1 concentrations [13], but besides the lower plasmatic concentrations of IGF-1 with undernutrition, no differences for hepatic IGF-1 mRNA expression were reported $[14,15]$. Therefore, decreased circulating IGF-1 concentrations could be due to post-transcriptional mechanism (e.g., similar transcription rate but decreased protein synthesis in undernutrition), but also to a reduction in total liver mass and thus IGF-1 total content.

There are no reports showing whether or not a relation between the decreased liver mass and a reduction in IGF-1 protein exists. In this study, whether the decrease in liver mass due to undernutrition is associated with a decrease in plasma IGF-1 concentrations and if the decrease in plasma IGF-1 concentrations is a response of a diminished IGF-1 protein or gene expression in the liver were investigated.

\section{Materials and Methods}

The study was conducted at the Experimental Farm of the University of Zaragoza, Spain (latitude $41^{\circ} \mathrm{N}$ ). All procedures were carried out under Project License PI05/10 approved by the in-house Ethics Committee for Animal Experiments from the University of Zaragoza. The care and use of animals were performed accordingly with the Spanish Policy for Animal Protection RD1201/05, which meets the European Union Directive 86/609 [16] on the protection of animals used for experimental and other scientific purposes.

\subsection{Experimental Design}

During the breeding season in mid-October, adult Rasa Aragonesa ewes were offered a diet that supplied the daily energy and protein requirements [15] to maintain a constant body condition score (BCS) during $30 \mathrm{~d}$. The diet consisted of $0.45 \mathrm{~kg}$ pellets and $0.55 \mathrm{~kg}$ barley straw per ewe per day, providing 8.37 MJ of metabolizable energy/ $\mathrm{kg}$ dry matter and $9 \%$ of crude protein (CP). After this period, ewes were oestrus synchronized (day 0 ) using intravaginal sponges that contained $30 \mathrm{mg}$ fluorogestone acetate (Chronogest, MSD, Madrid, Spain), which were inserted for $14 \mathrm{~d}$. At the time of sponge insertion, ewes were randomly assigned into two groups to provide either 1.5 times (control nutrition: $\mathrm{CN}$ ) or 0.5 times (low nutrition: LN) of the daily energy requirements for maintenance for $22 \mathrm{~d}$. In $\mathrm{CN}$ group, diets consisted of $0.60 \mathrm{~kg}$ of pellets and $0.90 \mathrm{~kg}$ of barley straw (13.20 MJ metabolizable energy/ewe/day), while in LN group, diets consisted of $0.20 \mathrm{~kg}$ of pellets and $0.30 \mathrm{~kg}$ of barley straw (4.4 MJ metabolizable energy/ewe/day). The occurrence of oestrus (day 0 ) was checked every $8 \mathrm{~h}$ using vasectomized rams. All ewes were mated with intact rams.

On day 7 of the synchronized oestrus cycle, animals were euthanized using sodium thiopental (Euta-Lender; Normon SA, Madrid, Spain). Prior to slaughter, live weight (12 h of fasting) and BCS was recorded. Animals were categorized in pregnant and non-pregnant according to the presence of the embryo within the uterus, after the euthanasia. Only pregnant ewes were considered, thus the final experimental groups were: nine $\mathrm{CN}$ ewes and seven $\mathrm{LN}$ ewes. Livers were dissected and weighed. Liver samples were obtained and formalin-fixed until embedded in paraffin or snap-frozen in liquid nitrogen and stored at $-80{ }^{\circ} \mathrm{C}$ until assayed. Since the weight of digest could not be registered during the sacrifice, the empty body 
weight (EBW) was estimated according to equations of Cornell Net Carbohydrate and Protein System (CNCPS) for sheep [16], as Eq. (1):

$$
\mathrm{EBW}=0.851 \times(\text { body weight } \times 0.96)
$$

\subsection{Blood Samples and Hormone Assay}

Jugular blood was sampled $1 \mathrm{~h}$ before feeding (08:00 am) at insertion and withdrawal of the pessaries, and at euthanasia (14 d before the oestrus, day 1 and day 7 , respectively). Samples were collected in heparinized tubes and centrifuged within $15 \mathrm{~min}$ of collection. Plasma was separated and stored at $-20^{\circ} \mathrm{C}$ until analysis.

Concentrations of IGF-1 were measured by a double antibody radioimmunoassay (RIA) [14]. Interference by IGF-1 binding proteins was minimized by acid-ethanol cryoprecipitation. The limit of detection was $0.49 \mathrm{ng} / \mathrm{mL}$. All samples were analyzed in one assay, and the intra-assay coefficients of variation (CVs) for low $(36.8 \mathrm{ng} / \mathrm{mL})$ and high $(520.2$ $\mathrm{ng} / \mathrm{mL}$ ) quality controls were $1.9 \%$ and $9.1 \%$.

\subsection{Immunohistochemistry}

An immunohistochemical technique (avidin-biotin-peroxidase), as previously described by Meikle et al. [17], was used to visualize IGF-1 immunostaining. Negative control was obtained by replacing the primary antibody with non-immune mouse IgG at equivalent concentration. The amount of IGF-1 was estimated subjectively by two independent observers who were not aware of treatment assignment. This peptide was evaluated in two hepatic compartments: epithelium and stoma. Ten fields were analyzed at a magnification of $\times 1,000$ in all ewes. The staining of the hepatocyte cytoplasm was scored as negative (-), faint (1), moderate (2) or intense (3), and the extent of staining was expressed in proportion on a scale $0-10$ [17]. The average staining was calculated as the method described by Boos et al. [18].

\subsection{RNA Isolation and Reverse Transcription}

Total RNA from liver was extracted using TRIzol
(Invitrogen, Carlsbad, CA, USA), followed by precipitation with lithium chloride and DNase-treatment with DNA-Free ${ }^{\mathrm{TM}}$ Kit (Ambion, Austin, TX, USA). Concentration of RNA was determined by measuring absorbance at $260 \mathrm{~nm}$, the purity of all RNA isolates was evaluated by the relation of $260 \mathrm{~nm}$ to $280 \mathrm{~nm}$ absorbance ratio and the integrity of the RNA was evaluated by electrophoresis ( $1 \%$ agarose gel). For each sample, cDNA was synthesized by reverse transcription using the SuperScript III transcriptase (Invitrogen) with oligo-dT primers and $1 \mu \mathrm{g}$ total RNA added as a template.

\subsection{Quantitative Real Time Polymerase Chain Reaction (PCR)}

Real time PCR reactions for IGF-1 (GenBank: NM_001009774.3) and the endogenous controls hypoxanthine-guanine phosphoribosyltransferase (HPRT) (GenBank: NM_001034035.2) and ribosomal protein L19 (RPL19) (GenBank: NM_001040516.1), were performed using $7.5 \mu \mathrm{L} \quad \mathrm{SYBR}{ }^{\circledR}$ Green master-mix (Quantimix EASY SYG kit, Biotools B\&M Labs, Madrid, Spain), equimolar amounts of forward and reverse primers (200 nM, Operon Biotechnologies $\mathrm{GmbH}$, Cologne, Germany) and $3 \mu \mathrm{L}$ diluted cDNA (1:7.5 in RNase/DNase free water) in a final volume of $15 \mu \mathrm{L}$. Samples were analyzed in duplicate in a 72-disk Rotor-Gene ${ }^{\mathrm{TM}} 6000$ (Corbett Life Sciences, Sydney, Australia). Standard amplification conditions were $3 \mathrm{~min}$ at $95{ }^{\circ} \mathrm{C}$ and 40 cycles of $15 \mathrm{~s}$ at $95^{\circ} \mathrm{C}, 40 \mathrm{~s}$ at $60^{\circ} \mathrm{C}$ and $10 \mathrm{~s}$ at $72{ }^{\circ} \mathrm{C}$. At the end of each run, dissociation curves were analyzed to ensure that the desired amplicon was detected and to discard contaminating DNA or primer dimers. Samples of cDNA of six ewes (three of each treatment) were pooled to provide an exogenous control, and five dilutions (from $100 \mathrm{ng} /$ tube to 6.25 $\mathrm{ng} /$ tube) of this pool were used to perform linear regression for each gene. The efficiency of the assays was calculated according to Eq. (2) [19]: 
Efficiency of the assays $=\left(10^{-1 / \text { slope }}-1\right)$

Gene expression was measured by relative quantification [20] to the exogenous control and normalized to the geometric mean expression of the endogenous control genes (HPRT and RPL19), taking into account the respective efficiencies [20]. Both HPRT and RPL19 have been used before as endogenous controls in liver [14], and their expression remained unchanged among samples in this study.

\subsection{Statistical Analysis}

All variables were analyzed by analysis of variance (SAS, Institute Inc., Cary, NC, USA) with a mixed model that included nutritional treatment (low or control) as fixed effect. In addition, the model to analyze the hepatocyte cytoplasmic staining included the effects of observer and treatment as a fixed effect, and the model for plasma IGF-1 included also the effect of the day. Data are presented as the least square means \pm standard errors. Means were considered different when $P \leq 0.05$.

\section{Results}

Different metabolic parameters in LN and $\mathrm{CN}$ ewes were shown in Table 1. In LN group, body weight of euthanized ewes was $63.9 \pm 0.4 \mathrm{~kg}$, whereas in $\mathrm{CN}$ group, it was $67.3 \pm 0.3 \mathrm{~kg}(P<0.01)$. EBW of ewe was decreased by $5 \%$ in LN group, while absolute liver mass was reduced by $22 \%$ when compared with control ewes $(P<0.01)$. Liver mass relative to EBW was also reduced by $25 \%$ in $\mathrm{LN}$ group when compared with $\mathrm{CN}$ ewes $(P<0.001)$. In this study, consistent with the $25 \%$ reduction in relative liver mass, plasma IGF-1 concentrations were decreased by $24 \%$ by undernutrition $(P<0.05)$. Nevertheless, no differences were observed between ewe groups neither in hepatic IGF-1 mRNA (Table 1) nor in IGF-1 immunostaning (Fig. 1). In the present study, IGF-1 immunostaining was located exclusively in the cytoplasm of the hepatocyte.

\section{Discussion}

The reductions in EBW and liver mass due to nutrient

Table 1 Different metabolic parameters in $L N$ and CN ewes on day 7 post-oestrus.

\begin{tabular}{llll}
\hline Parameters & LN & CN & \\
& $(0.5$ times of daily energy requirements $)$ & $(1.5$ times of daily energy requirements $)$ & $P$ value \\
\hline BW $(\mathrm{kg})$ & $63.9 \pm 0.40$ & $67.3 \pm 0.30$ & $<0.01$ \\
\hline EBW $(\mathrm{kg})$ & $52.2 \pm 0.33$ & $54.9 \pm 0.25$ & $<0.01$ \\
\hline Liver mass & & & $<0.01$ \\
\hline Absolute $(\mathrm{kg})$ & $0.63 \pm 0.04$ & $0.85 \pm 0.04$ & $<0.001$ \\
Relative $(\mathrm{g} / \mathrm{kg} \mathrm{EBW})$ & $1.21 \pm 0.07$ & $1.54 \pm 0.06$ & 0.05 \\
\hline Plasma IGF-1 $(\mathrm{ng} / \mathrm{mL})$ & $223.9 \pm 25.3$ & $295.6 \pm 25.3$ & 0.34
\end{tabular}

BW: body weight; EBW: empty body weight, $\mathrm{EBW}=0.851 \times(\mathrm{BW} \times 0.96)$.

Data are presented as least square means \pm standard errors.

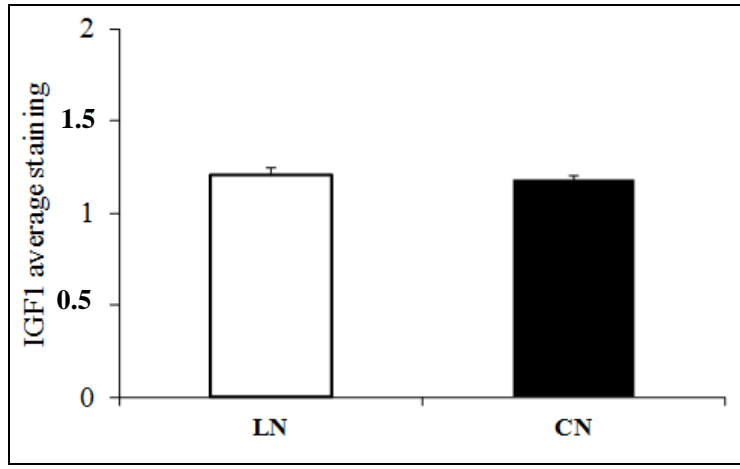

(a) Average immunoreactivity 


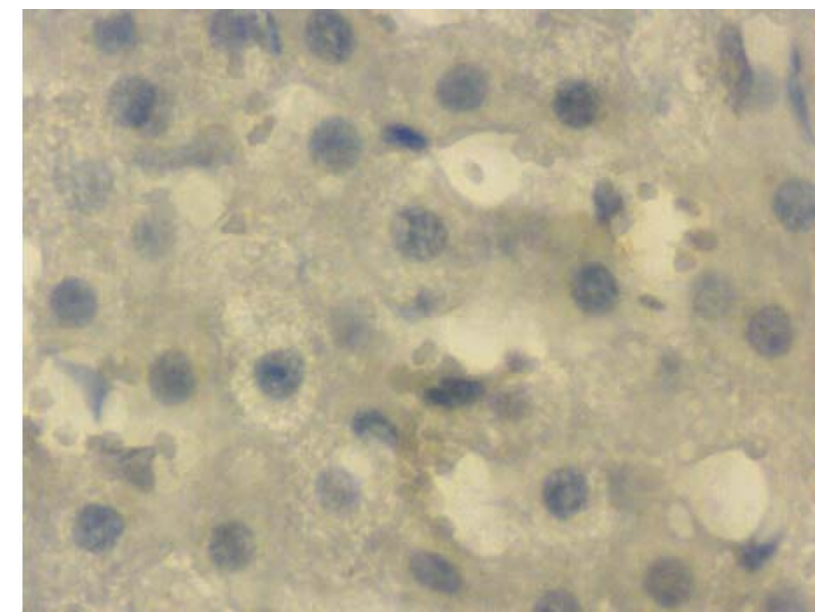

(b) Negative control $(40 \times)$

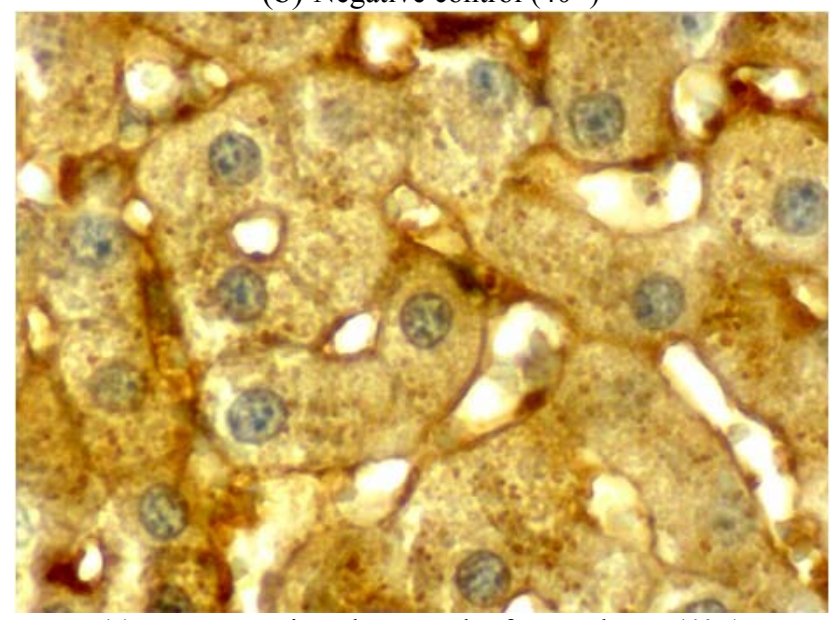

(c) Representative photograph of control ewe $(40 \times)$

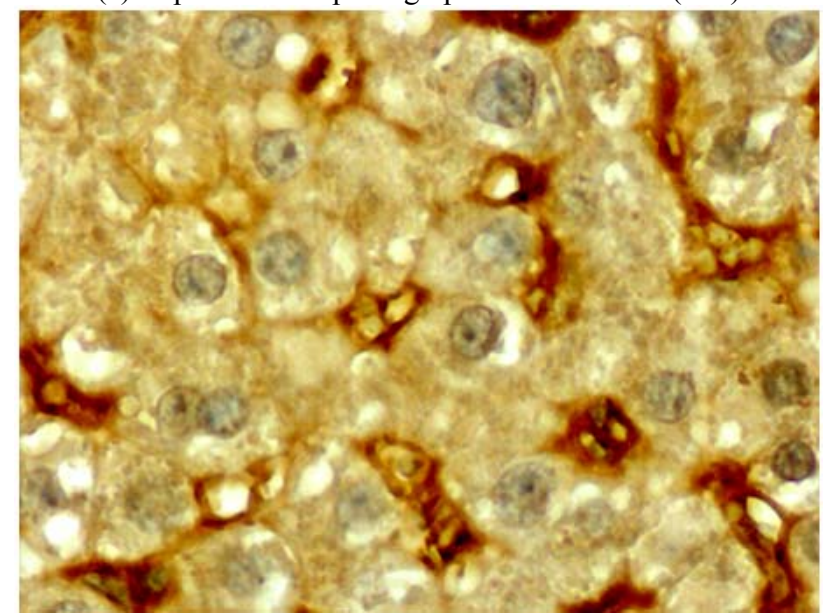

(d) Representative photograph of LN group (40×)

Fig. 1 Immunohistochemical localization of IGF-1 in liver of ewes fed 0.5 times (LN) or 1.5 times (CN) of the daily maintenance energy requirements during $22 \mathrm{~d}$.

restriction are consistent with previous reports [21, 22]. In concordance with Burrin et al. [21], these findings showed that liver mass (e.g., reduced cell size and/or number) changed more rapidly than body weight in response to undernutrition, illustrating the ability of these tissues to adapt rapidly to changing 
nutrient supply. In ruminants, portal blood flow is known to vary with metabolizable energy intake [1, 23], thus, in underfed animals, blood flow is reduced, leading to decreased liver nutrient absorption and in consequence a decreased liver mass.

It has been demonstrated in rats that the greatest rates of protein synthesis (e.g., IGF-1) occur in tissues, such as liver [24]. During a dietary restriction, evidence of reduced metabolic activity of the liver was apparent through less abundance of nutrient transporters. Additionally, Keogh et al. [25] observed evidence for a reduction in cell cycle processes, as well as a reduction in cellular proliferation and growth. Although the decrease in plasma IGF-1 concentrations is a mechanism of nutrient partitioning when nutrient availability is low, IGF-1 is a growth mediator that also affects the liver [26] and its decrease may lead to diminished cell number and size [27]. Although IGF-1 plasma concentrations were different between $\mathrm{CN}$ and LN ewes, no differences were found on hepatic IGF-1 immunoreactivity or IGF-1 mRNA. The lack of differences observed in IGF-1 mRNA between LN and $\mathrm{CN}$ was consistent with the previous finding by Sosa at al. [14] and those from others in beef and low milk producing dairy cows during the negative energy balance of early lactation [28]. Nevertheless, in contrast to the results in this study, Hiramatsu et al. [11] reported that fasted chicken presented lower hepatic IGF-1 immunostaining. This contradictory results could be due, among other factors, to differences in the specie (ewe vs. chicken), diets (half nutrition during $22 \mathrm{~d}$ vs. deprived of feed during $2 \mathrm{~d}$ ) and immunohistochemical techniques. The absence of differences in hepatic IGF-1 immunostaning between treatments suggested that non post-transcriptional processes were responsible for the reduction found in plasma IGF-1 concentrations of undernourished ewes. In this study, it is reported for the first time in sheep that IGF-1 is localized in the hepatocyte cytoplasm, as similarly found in rodents [29] and chicken [11].

Of interest, although liver-derived IGF-I has endocrine effects on extrahepatic tissues, there are only few data regarding local effects of this hormone in the liver, probably due to the very low amount of IGF-I receptors on the hepatocytes membrane. And this would also mean that liver-derived IGF-I would be unable to stimulate liver growth [30,31]. So the reduced liver mass found in the undernourished animals of this study may be a consequence of the reduced IGF-1 levels in serm, and would not be affected by the local transcript and protein.

\section{Conclusions}

These results of this study showed that the decreased liver mass in underfed ewes was associated with the decreased IGF-1 plasma concentration, and was independent of hepatic protein or mRNA expression. This suggest that plasma IGF-1 but no liver-derived IGF-1 is responsible for liver reduction mass in underfed ewes. To our knowledge, this is the first report showing the immunohistochemical localization of IGF-1 in sheep liver.

\section{Acknowledgments}

The authors thank Isabel Sartore for her technical assistance. This study was supported by grants from Diputación General de Aragón (DGA, A26) and MICINN (AGL2010-15004/GAN), Spain.

\section{References}

[1] Davis, S. R., Barry, T. N., and Hughson, G. A. 1981. "Protein Synthesis in Tissues of Growing Lambs." Brit. J. Nut. 46 (3): 409-19.

[2] Webster, A. J. F. 1981. "The Energetic Efficiency of Metabolism.” Proc. Nutr. Soc. 40: 121-8.

[3] Reynolds, C. K., Tyrrell, H. F., and Reynolds, P. J. 1991. "Effects of Diet Forage-To-Concentrate Ratio and Intake on Energy Metabolism in Growing Beef Heifers: Whole Body Energy and Nitrogen Balance and Visceral Heat Production.” J. Nut. 121 (7): 994-1003.

[4] Chilliard, Y., Bocquier, F., and Doreau, M. 1998. "Digestive and Metabolic Adaptations of Ruminants to Undernutrition and Consequences on Reproduction." Reprod. Nutr. Dev. 38 (2): 131-52.

[5] Koong, L. J., Nienaber, J. A., Pekas, J. C., and Yen, J. T. 
1982. "Effects of Plane of Nutrition on Organ Size and Fasting Heat Production in Pigs.” J. Nutr. 12 (8): 1638-42.

[6] Ferrell, C. L., and Koong, K. J. 1986. "Influence of Plane of Nutrition on Body Composition, Organ Size and Energy Utilization of Sprague-Dawley Rats.” J. Nutr. 116 (12): 2525-35.

[7] Schwander, J. C., Hauri, C., Zapf, J., and Froesch, E. R. 1983. "Synthesis and Secretion of Insulin-Like Growth Factor and Its Binding Protein by the Perfused Rat Liver: Dependence on Growth Hormone Status." Endocrinology 113 (1): 297-305.

[8] Stratikopoulos, E., Szabolcs, M., Dragatsis, I., Klinakis, A., and Efstratiadis, A. 2008. "The Hormonal Action of IGF-1 in Postnatal Mouse Growth." Proc. Natl. Acad. Sci. USA 105 (49): 19378-83.

[9] Butler, A. A., and LeRoith, D. 2001. "Minireview: Tissue-Specific versus Generalized Gene Targeting of the IGF-1 and IGF-1R Genes and Their Roles in Insulin-Like Growth Factor Physiology." Endocrinology 142 (5): 1685-8.

[10] Bestetti, G. E., Blum, J. W., and Rossi, G. L. 1992. "Immunohistochemistry of Hepatic IGF-I in Calf, Pig and Rat.” Zentralbl Veterinarmed A 39 (10): 747-51.

[11] Hiramatsu, K., Nagao, K., and Kita, K. 2004. "Localization of Insulin-Like Growth Factor-1 (IGF-1) in the Chicken Liver after Fasting and Refeeding: Demonstration by Using Antigen Retrieval Immunohistochemistry.” J. Vet. Med. Sci. 67 (4): 393-7.

[12] Ketelslegers, J. M., Maiter, D., Maes, M., Underwood, L. E., and Thissen, J. P. 1995. "Nutritional Regulation of Insulin-Like Growth Factor-1." Metabolism 44: 50-7.

[13] De Brun, V., Meikle, A., Casal, A., Sequeira, M., Contreras-Solís, I., Carriquiry, M., Sosa, C., and Abecia, J. A. 2015. "Endocrine Profiles and Hepatic Gene Expression in Control Ewes and Undernourished Pregnant and Non-pregnant Ewes." J. Anim. Phisiol. Anim. Nutr. 99 (4): 710-8.

[14] Sosa, C., Abecia, J. A., Carriquiry, M., Forcada, F., Martin, G. B., Palacin, I., and Meikle, A. 2009. "Early Pregnancy Alters the Metabolic Responses to Restricted Nutrition in Sheep." Domest. Anim. Endocrinol. 36 (1): 13-23.

[15] Cannas, A., Tedeschi, L. O., Fox, D. G., Pell, A. N., and Van Soest, P. J. 2004. "A Mechanistic Model for Predicting the Nutrient Requirements and Feed Biological Values for Sheep." J. Anim. Sci. 82 (1): 149-69.

[16] Government of Spain. 2013. "The Basic Norms Applicable for the Protection of Animals Used in Experimentation and Other Scientific Purposes, Including Teaching." Royal Decree 53/2013, Official State Bulletin No. 34.

[17] Meikle, A., Forsberg, M., Sahlin, L., Masironi, B.,
Tasende, C., Rodriguez-Pinon, M., and Garofalo, E. G. 2000. "A Biphasic Action of Estradiol on Estrogen and Progesterone Receptor Expression in the Lamb Uterus." Reprod. Nutr. Dev. 40 (3): 283-93.

[18] Boos, A., Meyer, W., Schwarz, R., and Grunert, E. 1996. "Immunohistochemical Assessment of Oestrogen Receptor and Progesterone Receptor Distribution in Biopsy Samples of the Bovine Endometrium Collected throughout the Oestrous Cycle." Anim. Reprod. Sci. 44 (1): 11-21.

[19] Rutledge, R. G., and Côté, C. 2003. "Mathematics of Quantitative Kinetic PCR and the Application of Standard Curves.” Nucleic Acids Res. 31 (16): e93.

[20] Pflaffl, M. W. 2001. “A New Mathematical Model for Relative Quantification in Real-Time RT-PCR.” Nucleic Acids Res. 29 (9): e45.

[21] Burrin, D. G., Ferrell, C. L., Britton, R. A., and Bauer, M. 1990. "Level of Nutrition and Visceral Organ Size and Metabolic Activity in Sheep." Brit. J. Nutr. 64 (2): 439-48.

[22] Marston, H. R. 1948. "The Fermentation of Cellulose in Vitro by Organisms from the Rumen of Sheep." Biochem. J. 42 (4): 564-74.

[23] Huntington, G. B., Eisemann, J. H., and Whitt, J. M. 1990. "Portal Blood Flow in Beef Steers: Comparison of Techniques and Relation to Hepatic Blood Flow, Cardiac Output and Oxygen Uptake." J. Anim. Sci. 68 (6): 1666-73.

[24] Webster, A. J. J. 1980. "The Energetic Efficiency of Growth.” Ann. Genet. Sel. Anim. 12 (1): 122-3.

[25] Keogh, K., Kenny, D. A., Cormican, P., Kelly, A. K., and Waters, S. M. 2016. "Effect of Dietary Restriction and Subsequent Re-alimentation on the Transcriptional Profile of Hepatic Tissue in Cattle." BMC Genomics 17: 244.

[26] Hayden, J. M., Williams, J. E., and Collier, R. J. 1993. "Plasma Growth Hormone, Insulin-Like Growth Factor, Insulin and Thyroid Hormone Association with Body Protein and Fat Accretion in Steers Undergoing Compensatory Gain after Dietary Energy Restriction." J. Anim. Sci. 71 (12): 3327-38.

[27] Demori, I., Balocco, S., Voci, A., and Fugassa, E. 2000. "Increased Insulin-Like Growth Factor Binding Protein-4 Expression after Partial Hepatectomy in the Rat." Am. J. Physiol.-Gastrointestinal and Liver Physiol. 278 (3): 384-9.

[28] Jiag, H., Lucy, M., Crooker, B., and Beal, W. 2005. "Expression of Growth Hormone Receptor 1A mRNA Is Decreased in Dairy Cows But Not in Beef Cows at Parturition.” J. Dairy Sci. 88 (4): 1370-7.

[29] Oner, J., Kus, I., and Oner, H. 2009. "Melatonin Increases the Expression of Insulin-Like Growth Factor-1 
in Rats with Carbontetrachlorid-Induced Hepatic Damage." J. Anim. Vet. Advance 8 (11): 2256-61.

[30] Sjogren, K., Liu, J. L., Blad, K., Skrtic, S., Vidal, O., Wallenius, V., LeRoith, D., Tornell, J., Isaksson, O. G., Jansson, J. O., and Ohlsson, C. 1999. "Liver-Derived Insulin-Like Growth Factor-1 (IGF-1) Is the Principal
Source of IGF-I in Blood But Is Not Required for Postnatal Body Growth in Mice." Proc. Natl. Acad. Sci. USA 96 (12): 7088-92.

[31] Puche, J. E., and Castillo-Cortázar, I. 2012. "Human Conditions of Insulin-Like Growth Factor-1 (IGF-1) Deficiency." J. Transl. Med. 10: 224. 